\title{
NANO-TECHNOLOGICAL PRODUCTS IN ARCHITECTURE AND CONSTRUCTION
}

\author{
S. Hernández-Moreno, S. C. Solache de la Torre \\ Universidad Autónoma del Estado de México \\ silverhm2002@yahoo.com.mx
}

Received 27/12/2016 - Accepted 12/04/2017

DOI: $10.15628 /$ holos.2017.5497

\section{ABSTRACT}

This work presents a review of the scientific literature that deals with the use of nanoscience and nanotechnology in architecture and construction industry in view of letting architects, builders, real estate promoters and interested parties know the scope that various nanomaterials, existing in the construction market could be used in this activities every-day from a sustainable and durable approach to architecture and construction. As a result we present, in an orderly and classified manner, a list of nano-products that can be applied to architecture and construction in building structures, covers and installations with an approach
\end{abstract}

based on the architectonic and constructive durability of each component. It is concluded that there are numerous nano-products with different uses and applications sufficient for some construction needs, with important applications such as: improvement of the durability and degradation of materials (mainly concrete and steel), the efficiency of equipment and devices such as batteries, photovoltaic cells, electrical conductors, OLED lamps, water filters, paints, sealants, windowpanes, electronical components, architectural finishes, among other products.

KEYWORDS: Nanotechnology, Nano-products, Nanomaterials, Construction, Architecture.

\section{NANOMATERIAIS APLICADOS EM ARQUITETURA E CONSTRUÇÃO}

\section{RESUMO}

Este trabalho apresenta uma revisão da literatura científica que trata do uso da nanociência e da nanotecnologia na arquitetura e na indústria da construção, com vistas a permitir que arquitetos, construtores, promotores imobiliários e interessados conheçam o escopo no qual vários nanomateriais existentes no mercado de construção possam ser utilizados em suas actividades do dia a dia, a partir de uma abordagem sustentável e durável para a arquitetura e construção. Como resultado, apresentamos, de forma ordenada e classificada, uma lista de nano-produtos que podem ser aplicados à arquitetura e construção em estruturas, coberturas e instalações com uma abordagem baseada na durabilidade arquitetônica e construtiva de cada componente. Conclui-se que existem inúmeros nanoprodutos com diferentes usos e aplicações suficientes para algumas necessidades de construção, com aplicações importantes como: melhoria da durabilidade e degradação de materiais (principalmente concreto e aço), eficiência de equipamentos e dispositivos como Baterias, células fotovoltaicas, condutores elétricos, lâmpadas OLED, filtros de água, tintas, vedantes, vidraças, componentes eletrônicos, acabamentos arquitetônicos, entre outros produtos.

PALAVRAS-CHAVE: Nanotecnologia, Nano-produtos, os nanomateriais, Construção, Arquitetura. 


\section{INTRODUCTION AND BACKGROUND}

\subsection{Introduction}

The objective and scope of the present paper is to offer an outline and introduction to the applications of nanotechnology in the fields of architecture and construction.

This paper is a review of information and scientific knowledge from worthy and reliable sources aiming to learn how and in which aspects the properties and characteristics of some materials, products and components might be improved for several application such as: steel and concrete structures, thermal insulation, bacterial repellents, intelligent sensors, photovoltaic panels, etc., by means of methods and techniques at the level of nanoscience.

Nano-science understood as the science that deals with the study and production of objects and materials that measure from 1 to 100 nanometers in at least one dimension (nm) (Nordlund, 2005; Kumar and Kumbhat, 2016).

This review addresses the scientific community related to construction industry, architects, builders, real estate developers and general public interested in solving various problems in construction and architecture with an approach in favor of durability, efficiency and sustainability of construction components over their service life.

Nowadays, research and development in nanoscience and nanotechnology live a great moment and have a promising future. It cannot be said it is living a boom, as there is still much to do, mainly in the applicability and implementation of nano-technological products at low costs and in an environmentally friendly way in construction industry; something still in process.

Many countries have a documented strategy to develop and research nanotechnology in which they establish their prospective for the use of nanotechnology in their development plans and that correlate the investment on nanotechnology with economic growth and development in their country or region. In these strategies, the opportunities and obstacles of the applications of nano-products in industrial sectors can be established; this can be very useful for the aforementioned development plans.

Some important references on the subject, such as Lindsay S.M. (2010), present a book in which it is stated that nanotechnology is the set of various disciplines, e.g., physics, chemistry, engineering or biology, and presents an integrated description of nanoscience, in which it is underscored that objects produced at nano-metric scale are complex to structure, since it is difficult to control in a laboratory, and even more in a factory, and requires the use of equipment, devices and methodologies translated into efficient computational models to execute this process.

The work relates nanoscience to clear bases on quantum mechanics, as it works at atomic scales. It presents a very useful section that refers to basic tools for the microscopic manipulation and objects. Applications in that paper mainly refer to biology, physics and chemistry and outlines in a general manner other applications in electronic, pharmaceutical and medicine industries. 
In other document referring to nanomaterials, Krishnamoorthy and Iniewski (2016) present a number of contributions in materials science and engineering on the application of nanomaterials in various fields of knowledge, including construction industry. They mention the nanomaterials' great impact on the improvement of numberless materials regarding durability, strengths, functionality and other properties of the materials. It is mentioned that most of the users and potential readers of the book can carry out the recommendations for applications in their area without being experts in the field of nanotechnology; this comes from several examples which are presented and taken as practical cases that can be repeated following the scientific method.

Cai et al. (2014) present production processes, properties and applications of micro- and nanostructured materials, making a classification based on the materials' composition, phases (understood as their physical state, in which variables such as temperature and chemical composition are related; this is to say, a phase can be defined as a homogeneous part of a system totally discernible from the other parts), shape, properties and distribution, defects and structural arrangements. This study underscores applications such as: properties to repel dust and dampness in glass, intelligent walls, thermal and optical properties, mechanical properties such as nanotubes (figure 1), devices to detect gases, which can be applied directly or indirectly in architecture and construction industry.

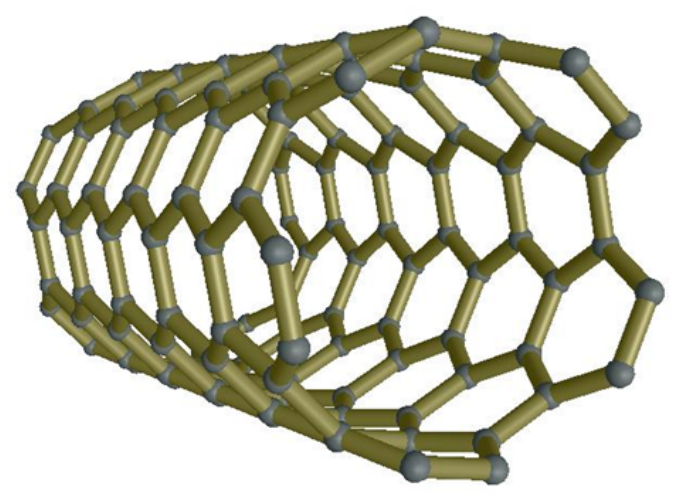

Figure 1. Section of carbon nanotube designed with a graphene mesh. (Source: Authors' own elaboration with ninithi ${ }^{\circledR}$ Nanotechnology Software).

Another document to consider as a referent (Gubicza, 2012) in the study of nanomaterials is the one related to structural defects in nanometric materials (Gubicza, 2012), in which methods and techniques to produce and process nanomaterials are described in order to learn and consider design structural defects. Structural defect in materials, produced for instance by structural dislocations derived from the particles' size of the raw material utilized, or from variables such as the materials' density, chemical composition and concentrations, or from the variability of temperature in manufacture processes and other mechanisms to change the materials' phase.

\subsection{Background}

Nanotechnology is a discipline that is part of the science of a several fields of knowledge (materials science, engineering, chemistry, physics, biology) understood as the control and 
restructuring of matter at the scale of nanometers $(\mathrm{nm})$, which uses particles under $100 \mathrm{~nm}$ (1 $\mathrm{nm}=10-9$ ) to create materials and objects with new properties and functions (NSTC-USA, 2007).

In architecture and construction industry, nanotechnology applications range from the improvement of the traditional properties of concrete (as anticorrosive protection), improve materials and products such as paints, sealants, glass to make them waterproof and repellent to bacteria and other noxious biological agents - , to the betterment of thermal and pyro-resistant properties as nano-compounds.

Nanotechnology has the potential to reduce environmental impacts and energy consumption in the manufacturing processes of products and materials used in construction; it can improve as well security and reduce costs associated with building works and infrastructure. Many an innovation based on nanotechnology has significant long-ranged repercussions that should be considered while using environmental design models such as LEED $^{\circledR}$ and BREEAM ${ }^{\circledR}$ in all kinds of projects (Guerrini and Corazza, 2008).

Regarding sustainability and environment, the application of nanotechnology can also be very useful, for instance in water purification processes, in the production of photovoltaic panels more efficient than the conventional ones or in the production of sensors for automated buildings, and also in the production of new batteries to ecologically store energy (Larramendy and Soloneski, 2016).

On the one hand, nanoparticles are materials at nanoscales that can go from 1 to $100 \mathrm{~nm}$ (Fahlman, 2011) and can take a number of shapes such as powders, crystals, pipes, meshes or fibers. To envisage the evolution of nanotechnology, for example, before the 1700's, the use of nanoparticles was limited to the production of high-quality glass of various colors to make stained glass, and ceramics and tiles (Larramendy and Soloneski, 2016).

The main problem in the application of nanomaterials (nanomaterial understood as several substances comprised in particle blocks at nano-metric scale, which produce some structured component) in architecture and construction industry is their current state of adaption and development, owing to commercial aspects, and also the frequent perception of elevated costs of nanotechnological products and their implementation in construction processes (Zhu et al., 2004). Conversely, in chemical, automotive, biomedicine and electronics industries, nanotechnology is well accepted mainly because of the volumes required, which compared with construction are much lower and the investment, more profitable, inasmuch as small quantities yield large revenues (Zhu et al., 2004).

Other problem nowadays identified about the application of nano-structured materials is the harm they may cause the environment at the end of their service life, in the cases in which there is poor handling in the final disposition of rejects or in the very manufacturing process, when they come into contact with living beings or are dispersed in air, water and soil, where they can have adverse reactions with the environment, as their biodegradation has not been thoroughly studied (EPA, 2014; Díaz-Soler et Al., 2016; West et Al., 2016).

In recent years there has been an increase in the evidence that human exposure to nano and micro particles is the cause of several diseases (Wohlleben et al., 2015). 
Another way in which nano-materials can affect the environment is that nano-particles readily bond to porous media, which are usually minerals in the subsoil and in aquatic environments (Bradley, 2010).

For example, the use of nano-silica with particle diameters between 15-25 nm used to produce a super hydrophobic polymer matrix paint, it was found that the optimum performance was with a nano-silica concentration of $2-3 \%$ by weight Of the matrix (Karmouch and Ross, 2010).

The design of new nano-systems allows managing an important and basic tool so that by means of tests and experiments practical solutions for a certain problem can be accomplished. The practical work to carry out in nano-design must be preferably at the last level, this is to say, between 1 and $100 \mathrm{~nm}$, specifically at molecular atomic level where the properties of matter appear and biologically life begins (Schommers, 2014).

Nano-design is attained by means of studies and experiments with equipment, devices and special computational methods of microscopy and advanced electronic nanoscopy such as: scanning electron microscopes, atomic force microscopy, scanning tunneling microscope, optical metrology, synthesis of carbon nano-tubes and micro-mechanical manipulation tests, with materials science experts; because of this, the scope of the present work is limited to a theoretical review of the literature from the standpoint of the architect.

In traditional or conventional technologies the scale is macro or micro, i.e., millimeters and centimeters at macro-level, and micrometers at micro, neither at a final level, the one that corresponds to nanometers, as previously indicated (Schommers, 2014).

Hence, the basic theory and computational tools for nano-design must be carefully selected since the complexity and dynamics at nano-metric scales are very sensitive and the nano-systems of sets or clusters of atoms, for instance, relate to functions and variables that can become critical.

It is also important to mention that nanomaterials are structured according to 3 dimensions:

a) One-dimension nanomaterials (1D)

b) Two-dimension nanomaterials (2D)

c) Three-dimension nanomaterials (3D)

One-dimension materials are those utilized as surfaces and thin films commonly in electronics and chemistry. In the case of construction industry, examples of application are: thin films to produce intelligent glass to regulate light and heat, and highly efficient photovoltaic cells (Yanfeng et Al., 2012).

Two-dimension nanomaterials structure as tubes (nanotubes) or wires (nanowires) and are utilized because of their excellent mechanical and electrical properties in various fields of knowledge. In construction industry, for instance, nanotubes (100 times more resistant than steel) at present used for producing Portland-cement-based concrete, increasing its mechanical strengths; while nanowires are used in electronic devices such as sensors and conductors in the automation of intelligent buildings (Šmilauer et Al., 2012). 
Three-dimension nanomaterials, as the name states, extend over three dimensions and the most representative example is the case of Fullerene (figure 2) $C_{60}$, which is a third allotropic form of carbon; it was discovered in 1985 by Harold Kroto, Robert Curl and Richard Smalley, and takes the name of Fullerene in honor of architect Richard B. Fuller, who already was building geodesic buildings based on hexagons and pentagons, whose symmetrical shape of truncated icosahedron ( 32 faces; 20 hexagons and 12 pentagons; 60 vertices and 90 edges to contain 60 carbon atoms in each vertex) was already known by Archimedes of Syracuse in 212 B.C. (Kharissova and Ortíz, 2002). It has the following applications in construction:

- Highly efficient lubricants

- Structural reinforcement in mechanical elements

- Superconductors

- Photovoltaic cells in combination with polymers

- Electro-chemical hydrogen conversion

- Styrene synthesis

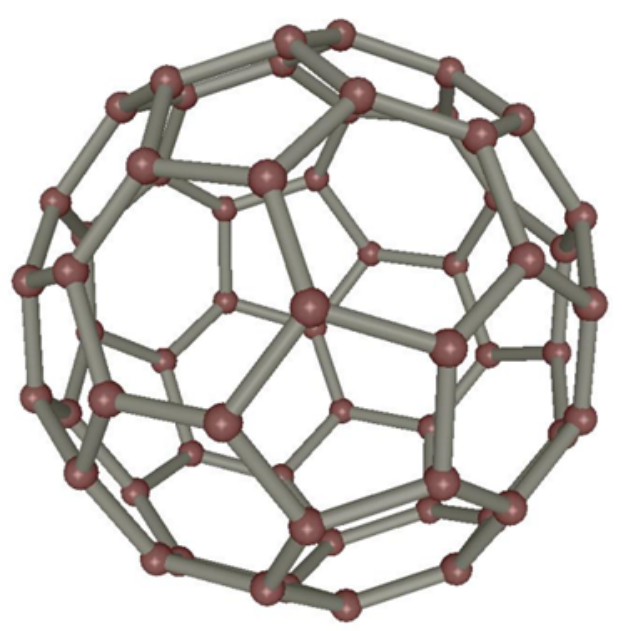

Figure 2. Fullerene C60, which is constituted of a third allotropic form of Carbon (Source: authors' own elaboration with ninithi ${ }^{\circledR}$ Nanotechnology Software).

Likewise, a number of nanoparticles are considered 3D as they reach sizes considered so by predefined measurements.

\section{METHODOLOGY}

A) Find out the general state of knowledge about the basic concepts of nanoscience and nanotechnology by means of revising the literature on the topic and its substantiation to understand the issue of application in the architectural and construction industry environment. This has been partly referred in the first section of this document (Introduction and Background) and responds to basic questions: what is nanoscience? And, what does nanotechnology mean? Also, what is the problem of applying nanotechnological products in architecture and construction in the world? This will be broadened in the revision of literature on theoretical and 
practical studies about the direct application of nanotechnology in construction industry in Results.

B) Review the main theoretical and practical studies about the application of nanotechnology in construction industry. In this phase we will review the state of scientific knowledge in studies which describe the advantages of certain nano-products successfully applied in construction in order to identify them according to their use in the industry by means of a review of the literature, data sheets of nano-products and databases of nanomaterials in view of ordering and classifying them.

C) Present the nano-products orderly, classified according to product, application and sustainable design (table 1).

\section{RESULTS}

3.1 Studies and current theoretical-practical reports that could work as a reference for the application of nanotechnology in architecture and construction

Sylvia Leydecker (Leydecker, 2008) focuses on indoor architectural and construction components and surface finishes, she begins with the concepts of nanotechnology and by means of studying the market of nano-products and ecological and economic aspects of design and functions and applications she reaches a proposal to use nano-products in architecture and construction classified as:

a) Products with self-cleaning capacity under the Lotus-Effect ${ }^{\circledR}$.

b) Products with self-cleaning capacity under the photo-catalysis effect, chemically understood as the acceleration of a photoreaction in the presence of a catalyst. It is catalyzed by photolysis, light absorbed by an adsorption of the substrate. In the photo-generated catalysis, the photo-catalytic activity (PCA) depends on the catalyzer capacity to produce pair holes of electrons, which generate free radicals capable of undergoing secondary reactions.

c) Products easy to clean and maintain

d) Air purifiers

e) Anti-condensation products

f) Indoor fragrance and aromatic capsules

g) Thermal insulation

h) Indoor temperature regulation

i) UV protection

j) Pyro-resistance

k) Anti-graffiti.

I) Anti-reflective protection

m) Anti-bacterial 
n) Anti-fingerprint marks

o) Resistance to abrasion and scratches

Another study that also refers to innovation in the surfaces of construction components in architecture was presented in Saarbrucken, Germany, by the company CC-NanoChem, which also focuses on interiors, furniture and architectural finishes (CC-NanoChem, 2010).

In a study referring to innovation in construction industry presented at an international conference on environment and technology, Yousef-Mohamed (2015) refers that nanotechnology has great potential for application in construction industry in spite of the high costs to acquire and develop nanotechnological products in developing countries, and puts forward a frame that relates the opportunities to apply nanotechnological products in sustainable construction with main bibliographic sources on studies dealing with sustainable design in architecture, nano-design, nanotechnology, introduction to nanomaterials, nanoarchiteture, nanotechnological innovation, environment in architecture and the environmental impacts and specific applications of nanomaterials. The author includes a list of nanostructured materials with uses in construction divided into structural and non-structural materials.

In a document dealing with nanotechnological innovation in construction industry, Hanus and Harris (2013) establish that the application of nanotechnology can considerably improve the performance of traditional construction materials such as concrete and steel, not only including mechanical strength but also durability and sustainability over their entire service life. For instance, using carbon nanotubes and nanofibers to improve strengths and durability of concrete, and even in order to protect steel from corrosion, coats of anticorrosive nano-polymers can be applied. The document includes not only aspects to improve mechanical strengths, but also treatments for surfaces with anti-microbial, and dust- and dampness-repelling characteristics, surfaces to purify air, insulating aerogels and photovoltaic solar cells.

Ashby et al. (2009) present an introduction to the design of nanomaterials and nanotechnology from an approach of engineers and architects with an evolutionary perspective for nanostructured materials with protective applications in art and historical-heritage buildings. This work takes the context of design and the architectural or engineering approach into account to enable the right selection and assessment of the most suitable nano-products to solve certain problems in buildings and infrastructure, encompassing construction volumes, sort of building and construction components as well as environmental aspects, building processes, modulation, design flexibility, workforce and costs of the project. The classification of nanostructured materials is made according to the sort and class of material, dividing them into metallic, ceramic, polymeric, compound, electronical, biomaterial, and also according to properties, mainly mechanical, thermal, electrical, magnetic, optical, acoustic and special cases such as nanotubes, nanofibers and other sorts of nano-compounds.

In the work by Pacheco-Torgal and Jalali (2011), nanotechnology is studied as the key that allows construction and new-materials industry to replicate their characteristics just as the natural systems were improved to perfection over millions of years that it took them together with evolution. This work is a review of literature about useful nanomaterials for applications in construction industry, basically focused on Portland-cement nanomaterials using nanoparticles to increase mechanical strengths and durability of cementing compounds by means of the photocatalytic capacities of nano-compounds. 
In Gao (2012), there are advances in polymeric nano-compounds with various applications in construction industry such as special coatings against abrasion, for instance in the production of batteries, fire retardants, with optical applications and especially in compounds based on polyvinyl chloride (PVC) that can be used as sealant and waterproofing materials for constructive joints or compounds based on nylon polymers that can also be utilized as reinforcement fibers, sealants, special paints or high-quality glues; nano-compounds based on polyethylene terephthalate (PET) with applications in the production of recyclable polymers; nano-compounds based on Polyurethane (PUR) to produce more resistant thermoplastics with various uses in paints, sealants and glues.

Although databases on nanostructured materials are good guides to search products, they are often incomplete and directly depend on the supplier's commercial information and sometimes they are not updated or may even contain errors. It is recommendable to consult the technical specs of the products directly from the manufacturer based on a specific need to solve in a determined part or construction component.

For instance, the Nanotechnology Products and Applications Database - Nanowerk (Nanowerk, 2016) applies for several industries and includes a listing of products for construction industry; the products are divided into three categories: a) concrete; b) steel; and, c) other. For its part, the entry on Concrete only considers two products, one to accelerate hardening and other to seal concrete surfaces. As for Steel, it contains four products, three are anticorrosive protectors for reinforce steel, other to reinforce ultra-resistant stainless steel utilized to lighten the weight of concrete structures. Finally, other contains 16 nano-products divided into four types: glass, insulators, paints, and protective coats. This same database contains other entries indirectly related to construction industry, for example, it contains an entry for the energy sector, divided as: a) distribution; b) generation; and, c) storage; and there is also an entry with products related to the environment, divided as: a) drinkable water filtration; b) non-potable filtration and depuration; c) remediation; and, d) waste water treatment. It also contains another entry related to Communications and Information Systems that contains 16 products and another entry on Transport with other 15 additional nanomaterials.

Another interesting database that contains information on nanomaterials for construction industry is elcosh-NANO (2016); it is not properly organized in large categories, however it is classified by sort of product, namely: additives, adhesives, coatings, glass, solar panels, insulators, lubricants, waterproofing and others. What is important in this database are the technical specs of materials, which have complete information on the product and on balance are a good guide for the contractor and planner. This information is summarized as follows:

- Category

- Technical description of the product

- Use

- Explains the reason for its use and application

- Information about the manufacturer 
3.2 Main nanotechnological products that can be used in architecture and construction

Table 1 summarizes the main nano-products and nanomaterials that can be utilized in architecture and construction from the architect's approach and in order to solve diverse problems in this activity sector.

Table 1. Main applications of various nanomaterials and nano-processes in construction and architecture industries

\begin{tabular}{|c|c|c|}
\hline $\begin{array}{c}\text { Nanomaterials } \\
\text { and nano- } \\
\text { processes }\end{array}$ & $\begin{array}{c}\text { Main applications in construction and } \\
\text { architecture }\end{array}$ & Sustainable design \\
\hline Carbon nanotubes & $\begin{array}{l}\text { Concrete and steel structures to increase } \\
\text { mechanical strengths in buildings and machines. } \\
\text { Highly resistant glues in combination with } \\
\text { polymers } \\
\text { Increment anticorrosive protection in } \\
\text { building structures } \\
\text { Diminution of weight in building structures } \\
\text { Improve lithium batteries } \\
\text { Conductors, semiconductors and } \\
\text { superconductors } \\
\text { Separation of oxygen from air (graphene } \\
\text { membranes) }\end{array}$ & $\begin{array}{l}\text { Increment in durability, strengths } \\
\text { and service life of structures and } \\
\text { components } \\
\text { Efficiency in the use of energy }\end{array}$ \\
\hline Fullerene & $\begin{array}{l}\text { Highly efficient lubricants } \\
\text { Structural reinforcement in mechanical elements } \\
\text { Superconductors } \\
\text { Photovoltaic cells in combination with polymers } \\
\text { Hydrogen electrochemical conversion } \\
\text { Styrene synthesis }\end{array}$ & $\begin{array}{l}\text { Increase in durability, strengths } \\
\text { and service life of structures and } \\
\text { components } \\
\text { Efficiency in the use of energy }\end{array}$ \\
\hline $\begin{array}{l}\text { Semiconductor } \\
\text { nanostructure } \\
\text { (quantum dots) }\end{array}$ & $\begin{array}{l}\text { Computer screens, tablets and cellular phones } \\
\text { LED lightning } \\
\text { Photovoltaic cells } \\
\text { Intelligent semiconductors }\end{array}$ & Efficiency in the use of energy \\
\hline $\begin{array}{c}\text { Nanowires } \\
\text { Zinc oxide nanowires } \\
\text { Silica oxide } \\
\text { nanowires in }\end{array}$ & $\begin{array}{l}\text { In combination with graphene these nanowires } \\
\text { are used to produce new photovoltaic solar cells, } \\
\text { solar concentrators, light sensors and nano-sensors } \\
\text { Highly efficient batteries to store energy }\end{array}$ & $\begin{array}{l}\text { Efficiency in the use of } \\
\text { energy }\end{array}$ \\
\hline
\end{tabular}




\begin{tabular}{|c|c|c|}
\hline $\begin{array}{l}\text { combination with } \\
\text { nano-polymers }\end{array}$ & & \\
\hline $\begin{array}{c}\text { Carbon } \\
\text { nanomaterials }\end{array}$ & Batteries and other energy-related devices & $\begin{array}{l}\text { Efficiency in the use of } \\
\text { energy. }\end{array}$ \\
\hline $\begin{array}{l}\text { Silica nanoparticles } \\
\text { or nano-silica }\end{array}$ & $\begin{array}{l}\text { Consolidation of concretes, mortars and other } \\
\text { compound materials } \\
\text { Solar protection } \\
\text { Self-cleaning paints } \\
\text { Dampness repellents } \\
\text { Antireflection } \\
\text { Compounds for new photovoltaic cells } \\
\text { Protection of reinforcement steel against } \\
\text { corrosion and other deterioration agents } \\
\text { Reduction of efflorescence in concrete } \\
\text { Additive to join old and new concrete }\end{array}$ & $\begin{array}{l}\begin{array}{l}\text { Increase in durability and } \\
\text { service life of structures and } \\
\text { components. }\end{array} \\
\text { Efficiency in the use of energy } \\
\text { Increase in durability and service } \\
\text { life of structures and components }\end{array}$ \\
\hline $\begin{array}{l}\text { Nanoparticles of } \\
\text { titanium oxides and } \\
\text { dioxides }\end{array}$ & $\begin{array}{l}\text { Improve mechanical strengths of any compound } \\
\text { as well as waterproofing and sealing of concrete } \\
\text { surfaces } \\
\text { Self-cleaning membrane by photo-catalysis effect. } \\
\text { Anti-condensation films } \\
\text { Photovoltaic cells }\end{array}$ & $\begin{array}{l}\text { Increase in durability and service } \\
\text { life of structures and components } \\
\text { Efficiency in the use of energy. }\end{array}$ \\
\hline $\begin{array}{l}\text { Fiber of } \\
\text { nanostructured } \\
\text { ceramic }\end{array}$ & $\begin{array}{l}\text { Improves flexion and contraction strengths of } \\
\text { materials }\end{array}$ & $\begin{array}{l}\text { Increase in durability and service } \\
\text { life of structures and components }\end{array}$ \\
\hline Silica fume & $\begin{array}{l}\text { Reduce the use of Portland cement and improves } \\
\text { mechanical strength and durability of the concrete } \\
\text { and mortar mixtures }\end{array}$ & $\begin{array}{l}\text { Increase in durability and } \\
\text { service life of structures and } \\
\text { components }\end{array}$ \\
\hline Zeolites & Non-porous absorbent materials for energy storing & $\begin{array}{l}\text { Efficiency in the use of } \\
\text { energy. }\end{array}$ \\
\hline Crystal nanoparticles & Help for fast concrete curing and its control. & \\
\hline $\begin{array}{l}\text { Nanoparticles and } \\
\text { nano-alloys of } \\
\text { Aluminum and copper }\end{array}$ & $\begin{array}{l}\text { Anticorrosion of metals and reinforcement steel } \\
\text { Resistance to abrasion and corrosive agents } \\
\text { Anti-scratches } \\
\text { Shape memory materials }\end{array}$ & $\begin{array}{l}\text { Increase in durability and } \\
\text { service life of structures and } \\
\text { components }\end{array}$ \\
\hline $\begin{array}{l}\text { Nanostructured } \\
\text { acrylic glass }\end{array}$ & $\begin{array}{l}\text { Windowpanes and covers of high resistance to } \\
\text { impact and outdoor conditions }\end{array}$ & \\
\hline $\begin{array}{l}\text { Nanostructured and } \\
\text { nano-compounded }\end{array}$ & $\begin{array}{l}\text { Intelligent glass, thermal and acoustic insulation; } \\
\text { low reflectivity, solar filter for UV protection and }\end{array}$ & Efficiency in the use of \\
\hline
\end{tabular}




\begin{tabular}{|c|c|c|}
\hline films & self-cleaning glass & energy. \\
\hline $\begin{array}{l}\text { Nano-compounds of } \\
\text { various polymers }\end{array}$ & $\begin{array}{l}\text { Highly efficient long-lasting paints and sealing } \\
\text { products } \\
\text { Paint hardeners and sealants } \\
\text { Water filters } \\
\text { Anti-graffiti } \\
\text { Repellent to dampness and dust } \\
\text { Anti-bacterial paint } \\
\text { Thermal insulation in buildings }\end{array}$ & $\begin{array}{l}\text { Increase in durability and service } \\
\text { life of structures and components } \\
\text { Efficiency in the use of energy. } \\
\text { Increase in durability and service } \\
\text { life of structures and components } \\
\text { Efficiency in the use of energy }\end{array}$ \\
\hline $\begin{array}{l}\text { Aluminium oxide } \\
\text { nanoparticles }\end{array}$ & $\begin{array}{l}\text { Improve resistance to damage from UV radiation } \\
\text { in surfaces (mainly wood) }\end{array}$ & $\begin{array}{l}\text { Increase in durability and } \\
\text { service life of structures and } \\
\text { components }\end{array}$ \\
\hline $\begin{array}{c}\text { Graphene } \\
\text { nanoplatelets } \\
\text { Graphene } \\
\text { nanoparticles }\end{array}$ & $\begin{array}{l}\text { To complement adhesive works on surfaces, } \\
\text { sealing and waterproofing } \\
\text { Highly-efficient batteries }\end{array}$ & $\begin{array}{l}\text { Increase in durability and } \\
\text { service life of structures and } \\
\text { components } \\
\text { Efficiency in the use of } \\
\text { energy }\end{array}$ \\
\hline $\begin{array}{l}\text { Graphene nano- } \\
\text { fibers }\end{array}$ & Glue, sealant and re-modeler & $\begin{array}{l}\text { Increase in durability and } \\
\text { service life of structures and } \\
\text { components }\end{array}$ \\
\hline $\begin{array}{l}\text { Magnesium } \\
\text { nanoparticles }\end{array}$ & $\begin{array}{l}\text { Useful as protection for surfaces subject to } \\
\text { corrosion, dampness and oxidation }\end{array}$ & $\begin{array}{l}\text { Increase in durability and } \\
\text { service life of structures and } \\
\text { components }\end{array}$ \\
\hline $\begin{array}{r}\text { Polycarbonate } \\
\text { nanotechnology }\end{array}$ & $\begin{array}{l}\text { Useful as protection for surfaces subject to } \\
\text { corrosion, dampness and oxidation }\end{array}$ & $\begin{array}{l}\text { Increase in durability and } \\
\text { service life of structures and } \\
\text { components }\end{array}$ \\
\hline $\begin{array}{l}\text { Nanostructured } \\
\text { membranes }\end{array}$ & $\begin{array}{l}\begin{array}{l}\text { Sequestering and deposition of carbon dioxide } \\
\text { (graphene membranes) }\end{array} \\
\text { Performance and durability in fuel cells } \\
\text { Waste water treatment based on modules of } \\
\text { graphene members } \\
\text { High-density storage of data and information } \\
\text { Optical storage of data } \\
\text { Protection against dampness, oxygen and micro- } \\
\text { particles in electronic components such as Organic } \\
\text { Light Emitting Diodes (OLED) and Organic } \\
\text { Photovoltaics (OPV) } \\
\text { Refractories in electronics and spintronics } \\
\text { Anti-oxide and ultra-adherent protection in }\end{array}$ & $\begin{array}{l}\text { Efficiency in the use of } \\
\text { energy } \\
\text { Efficiency in the use of } \\
\text { water } \\
\text { Increase in durability and } \\
\text { service life of structures and } \\
\text { components }\end{array}$ \\
\hline
\end{tabular}




\begin{tabular}{|c|c|c|}
\hline & $\begin{array}{l}\text { (metallic, ceramic and polymeric) components in } \\
\text { electronic circuit boards } \\
\text { Computer chips } \\
\text { Components of computer screens, touch-screen } \\
\text { interfaces in "intelligent buildings", telephones, } \\
\text { tablets, etc. } \\
\text { Dust repellent in electronic components, mainly in } \\
\text { parts of polymeric material } \\
\text { Air purifiers } \\
\text { Anti-condensation } \\
\text { Pyro-resistant covers } \\
\text { UV protection and regulators of visible light and } \\
\text { UV radiation (membranes of titanium dioxide, zinc } \\
\text { oxide and cerium oxide) }\end{array}$ & $\begin{array}{l}\text { Efficiency in the use of } \\
\text { energy } \\
\text { Quality in air and indoor } \\
\text { comfort } \\
\text { Efficiency in the use of } \\
\text { energy }\end{array}$ \\
\hline $\begin{array}{l}\text { Nanostructured thin } \\
\text { films }\end{array}$ & $\begin{array}{l}\text { Photovoltaic cells and other solar photo- } \\
\text { concentrators } \\
\text { Electronic filters } \\
\text { Anti-graffiti } \\
\text { Anti-digital fingerprint } \\
\text { UV protection } \\
\text { Thermal and acoustic insulator in building } \\
\text { envelopes } \\
\text { Visible light regulators for glass and covers }\end{array}$ & $\begin{array}{l}\text { Efficiency in the use of } \\
\text { energy } \\
\text { Efficiency in the use of } \\
\text { energy }\end{array}$ \\
\hline $\begin{array}{l}\text { Nanostructured } \\
\text { lithium }\end{array}$ & Highly-efficient and durable batteries & $\begin{array}{l}\text { Efficiency in the use of } \\
\text { energy }\end{array}$ \\
\hline $\begin{array}{c}\text { Polarizable } \\
\text { electrodes of } \\
\text { nanostructured } \\
\text { materials }\end{array}$ & Super capacitors to save energy in the systems & $\begin{array}{l}\text { Efficiency in the use of } \\
\text { energy }\end{array}$ \\
\hline Nano-alumina & Water filters & $\begin{array}{l}\text { Efficiency in the use of } \\
\text { water }\end{array}$ \\
\hline $\begin{array}{l}\text { Nanostructured } \\
\text { magnetic foam }\end{array}$ & $\begin{array}{l}\text { Application to remediate soils and water polluted } \\
\text { by oil and byproducts. }\end{array}$ & $\begin{array}{l}\text { Improvement of the place } \\
\text { and its biotic and abiotic resources }\end{array}$ \\
\hline Nano-gel and aerogel & $\begin{array}{l}\text { Remediation and recovery of ecological } \\
\text { environments } \\
\text { Thermal insulator in building envelopes (silica } \\
\text { dioxide aerogel) }\end{array}$ & $\begin{array}{l}\text { Improvement of the place } \\
\text { and its biotic and abiotic resources } \\
\text { Efficiency in the use of } \\
\text { energy }\end{array}$ \\
\hline Nano-metric & Waste water treatment based on an oxidation, & Efficiency in the use of \\
\hline
\end{tabular}




\begin{tabular}{|c|c|c|}
\hline cavitation & ozone and nano-metric cavitation reactor & water \\
\hline Nano-catalyst & Waste water treatment & $\begin{array}{c}\text { Efficiency in the use of } \\
\text { water }\end{array}$ \\
\hline $\begin{array}{c}\text { Special } \\
\text { nanostructured } \\
\text { cathodes }\end{array}$ & $\begin{array}{c}\text { Nanostructured technology that reduces heat in } \\
\text { electronic parts }\end{array}$ & $\begin{array}{c}\text { Efficiency in the use of } \\
\text { energy }\end{array}$ \\
\hline $\begin{array}{c}\text { Nano-powders } \\
\text { Aneat-dissipating components in electronics } \\
\text { Indoor fragrance capsules } \\
\text { Anti-bacterial paint }\end{array}$ & $\begin{array}{c}\text { Efficiency in the use of } \\
\text { energy } \\
\text { Quality in air and indoor } \\
\text { comfort }\end{array}$ \\
\hline
\end{tabular}

Sources: Elcosh-NANO, 2016; Nanowerk, 2016; Sánchez and Sobolev, 2010; Leydecker, 2008;

Krishnamoorthy and Iniewski, 2016.

Table 1 explicitly refers to the summary of nanotechnological products in order to summarize the applications and main uses of nano-products and how these can be applied in construction industry. In column 3 of the table 1, the basic aspects of sustainable design of building products are shown, distinguishing aspects on durable design and service life.

\section{DISCUSSION AND CONCLUSIONS}

Nanotechnology in construction industry is not fully developed; there is still much to do, mainly in reducing their manufacture costs for massive use and safe applicability as in other fields (electronics and medicine).

Another important aspect of what is needed to do in nanotechnology and nanomaterials is related to the improvement in security and control over the entire life cycle of nanotechnological products, mainly environmental aspects during the last phase of their service life, as most of the environmental (mainly noxious) effects that some nanostructured materials might produce are unknown.

However, the development of new nanostructured materials marches on and a promising future in design, research, innovation and development for numberless applications in all industries and fields of knowledge (mainly in carbon-based nanostructured materials, mainly fullerene and graphene) is glimpsed, and construction industry is not an exception.

In construction industry, the main applications revolve around the improvement of concrete properties (mechanical strengths), the improvement of the anticorrosive protection of reinforcement steel, repelling dampness through the use of paints, sealants and varnishes that also improve dust and bacteria repellence, in the production of photovoltaic cells and highlyefficient batteries, to produce components such as intelligent walls and windowpanes for thermal and acoustic insulation, in the production of numberless electronic pieces and components with applications in intelligent buildings, special installations, etc. 
The development of new nanostructured materials in various shapes and forms: powders, fibers, tubes, membranes, films, wires, cables, etc. which means that frequently the shape determines the functionality that a nanomaterial has in relation to a macro-material (in bulk); a good instance of this would be the inclusion of carbon nanotubes and silica nano-powders to reinforce Portland cement concrete to be used in structures and building envelopes. Another example is the use of thin films to regulate UV rays inside the buildings and also to reduce the entrance of radiation and excessive heat to the buildings, thus creating more conformable and healthy spaces.

Frequently, the design and development of new materials is commonly carried out by chemists, industrial engineers and in areas related to materials science and that is good to occur because they are specialists, however most of the times, the architect does not take part in the process and at present it is considered that works to develop new materials for construction industry would have to be approached in a multidisciplinary way and consider the architect's decisive intervention.

For increase these applications in the fields of architecture and construction, apart from the investment on research and development, will basically depends on the sort of proposals made in those fields by architects with scientific training, unfortunately, today there are no studies done by architects demonstrating development in the field of nanomaterials.

\section{REFERENCES}

Ashby Michael F., Ferreira Paulo J. and Schodek Daniel L. (2009). Nanomaterials, Nanotechnologies and Design, The Netherlands: ELSEVIER.

Bradley, J. (2010). "Nanotech's Evolving Environmental Health, and Safety Landscape", Presentation at Nanosafe 2010: International Conference on Safe Production and Use of Nanomaterials, Nov. 16-18, 2010, Minatec, France [online]. Available: http://www.nanosafe.org/home/liblocal/docs/Nanosafe\%202010/2010_oral\%20presentatio ns/PLOa_Bradley.pdf [accessed Dec. 17, 2010].

Cai Weiping, Duan Guotao, Yue Li Yue. (2014). Hierarchical Micro/Nanostructured Materials Fabrication: Properties and Applications, Boca Raton, FL, USA: Taylor \& Francis Group, LLC.

CC-NanoChem (2010). New Surfaces in Architecture, Furniture and Design, Annual Oneday Seminar on "Innovation through Nanotechnology", Saarbrucken, Germany.

Díaz-Soler Beatriz María, Martínez-Aires María Dolores, López-Alonso Mónica (2016). Emerging risk in the construction industry: Recommendations for managing exposure to nanomaterials, DYNA, 83 (196), pp. 48-54.

Drexler KE, Peterson C, Pergamit G. (1991). Unbounding the future: the nanotechnology revolution, New York: William Morrow Editors.

Elcosh-NANO (2016). CPWR- The Center for Construction Research and Training. Consulted on June 1st, 2016, at: http://nano.elcosh.org/

EPA (2014). Technical Fact sheet -Nanomaterials, U.S. USA: Environmental Protection Agency. 
Fahlman BD. (2011). What is Materials Chemistry? New York: Springer. DOI: 10.1007/978-94-0070693-4

Feynman R. (1960). There's plenty of room at the bottom (reprint from the speech given at the annual meeting of the West Coast section of the American Physical Society. Eng Sci, 1960 (23), pp.22-36.

Gao, Fengge. (2012). Advances in polymer nanocomposites: types and applications, UK: Woodhead Publishing Limited.

Gubicza Jenó. (2012). Defect structure in nanomaterials, Cambridge, UK: Woodhead Publishing Limited.

Guerrini GL, Corazza F. (2008). White cement and photocatalysis. Part 2: applications. In: "First Arab international conference and exhibition on the uses of white cement", Cairo, Egypt; 2830 April, 2008.

Hanus Monica J., Harris Andrew T. (2013). Nanotechnology innovations for the construction industry, Progress in Materials Science, 58 (2013), pp. 1056-1102. http://dx.doi.org/10.1016/j.pmatsci.2013.04.001

Karmouch, R. and G. G. Ross. (2010). Superhydrophobic wind turbine blade surfaces obtained by a simple deposition of silica nanoparticles embedded in epoxy, Appl Surf Sci, 257 (3): 665669.

Kharissova Vasilievna and Ortíz Méndez Ubaldo. (2002). La estructura del fullereno C60 y sus aplicaciones, Ciencia UANL, Volume V, number 4, pp. 475-479.

Krishnamoorthy, Sivashankar and Iniewski, Krzysztof. (2016). Nanomaterials: a Guide to Fabrication and Applications, USA: Taylor \& Francis Group, LLC.

Kumar Narendra and Kumbhat Sunita. (2016). Essentials in nanoscience and nanotechnology, New Jersey, EUA: John Wiley \& Sons.

Larramendy Marcelo L. and Soloneski Sonia. (2016). Green Nanotechnology Overview and Further Prospects, Publishing Process Manager.

Leydecker Sylvia (2008). Nano Materials in Architecture, Interior Architecture and Design, Germany: BirkhauserVerlag AG.

Lindsay S.M. (2010). Introduction to Nanoscience, United Kingdom: Oxford University Press.

Nanowerk (2016). Web page consulted on June 1st, 2016, at: http://www.nanowerk.com/products/products.php

Nordlund K. (2005) Introduction to Nanoscience, consulted on June 29th, 2016, at: http://www.acclab.helsinki.fi/ knordlun/nanotiede/nanosc1nc.pdf

NSTC USA (2007). "The National Nanotechnology Initiative - Strategic Plan", December 2007. Executive Office of the President of the United States; 2007.

Pacheco-Torgal F. and Jalali Said. (2011). Nanotechnology: Advantages and drawbacks in the field of construction and building materials, Construction and Building Materials, 25 (2011), pp. 582-590. doi:10.1016/j.conbuildmat.2010.07.009 
Sánchez Florence and Sobolev Konstantin. (2010). Nanotechnology in concrete - A review, Construction and Building Materials, 24 (2010), pp. 2060-2071. http://dx.doi.org/10.1016/j.conbuildmat.2010.03.014

Schommers, W. (2014). Nano-design: some basic questions, Germany: Karlsruhe Institut für Technologie (KIT).

Sobolev K, Ferrada-Gutiérrez M. (2005). How nanotechnology can change the concrete world: Part 1, American Ceramic Society Bulletin, 84 (10), pp.14-17.

Šmilauer, V., Hlavácek, P., Padevet, P. (2012). Micromechanical analysis of cement paste with carbon nanotubes. Acta Polytechnica, 52 (6), pp. 22-28.

West Gavin H., Lippy Bruce E., Cooper Michael R., Marsick Daniel, Burrelli Leonard G., Griffin Kelsey N., Segrave Alan M. (2016). Toward responsible development and effective risk management of nano-enabled products in the U.S. construction industry, J Nanopart Res (2016), pp. 18-49. DOI 10.1007/s11051-016-3352-y.

Wohlleben Wendel, Kuhlbusch Thomas A. J., Schnekenburger Jürgen, Lehr Claus-Michael (2015). Safety of nano-materials along their lifecycle, Boca Raton FL, USA: CRC Press, Taylor \& Francis Group.

Yanfeng Gao, Hongjie Luo, Zongtao Zhang, Litao Kang, Zhang Chen, Jing Du, Minoru Kanehira, Chuanxiang Cao. (2012). Nanoceramic $\mathrm{VO}_{2}$ thermochromic smart glass: A review on progress in solution processing, Nano Energy, 1, (2), pp. 221-246; ISSN: 2211-2855, http://dx.doi.org/10.1016/j.nanoen.2011.12.002.

Yousef Mohamed Abeer Samy (2015). "Nano-Innovation in Construction, A New Era of Sustainability", 2015 International Conference on Environment And Civil Engineering (ICEACE'2015), April 24-25, 2015 Pattaya (Thailand).

Zhu W, Bartos PJM, Porro A. (2004). Application of nanotechnology in construction. Summary of a state-of-the-art report. Materials and Structures, 2004 (37), pp. 649-58. 